Campaigning for Votes in Ancient Pompeii: Contextualizing Electoral Programmata

\author{
Viitanen, Eeva-Maria \\ de Gruyter \\ 2017-08
}

Viitanen , E-M \& Nissin , L 2017 , Campaigning for Votes in Ancient Pompeii:

Contextualizing Electoral Programmata . in I Berti , K Bolle, F Opdenhoff \& F Stroth (eds), Writing Matters : Presenting and Perceiving Monumental Inscriptions in Antiquity and the Middle Ages . de Gruyter , pp. 117-144 . https://doi.org/10.1515/9783110534597-006

http://hdl.handle.net/10138/232723

https://doi.org/10.1515/9783110534597-006

cc_by_nc_nd

publishedVersion

Downloaded from Helda, University of Helsinki institutional repository.

This is an electronic reprint of the original article.

This reprint may differ from the original in pagination and typographic detail.

Please cite the original version. 


\section{Campaigning for Votes in Ancient Pompeii: Contextualizing Electoral Programmata}

\section{Introduction}

Analyzing inscriptions in their spatial contexts has become a very welcome trend in Classics in recent years. The contents of inscriptions have been studied and discussed in great detail, but little attention has been paid to the question what the find context could mean for the interpretation of the text and its significance. ${ }^{1}$ However, it sometimes still seems that the texts themselves are more interesting to scholars than their contextualization. Is it enough for instance, to take one group of inscriptions defined by their content and place them on a map of a site? Does this add a genuine new level of context into the interpretation? What about all the other inscriptions found at the site? Where are they located compared to this particular group? Are different kinds of texts commonly found in similar places? What are the exact locations where the inscriptions were placed? A broader approach to contextualization is necessary if the texts are to be understood in their contexts. Distribution of a single group of texts needs to be compared to distributions of others and the detailed elements of the individual archaeological context need to be taken into consideration. It is understandable why this kind of work is still quite rare: there are hardly any easily usable data sets available and finding the relevant data for a variety of analytical elements requires a lot of time and effort.

The main aim of the project "Inscribed Texts in their Spatial Contexts in Roman Italy"2 was to combine philological and archaeological expertise in order to analyze both the content of the texts and the archaeology of their contexts. Texts painted, scratched or written with coal or chalk on the façades of the city blocks of Pompeii were one of the main topics. The main question was why the texts were written where they were found. The hypothesis was that these wall inscriptions were related to places where people moved or hung out for periods of time. The main task was to place the

\footnotetext{
Laura Nissin has worked on the collection and mapping of the textual data and Eeva-Maria Viitanen has been responsible for the archaeological data and the analyses. Language revision was conducted by Mrs. Sirkku Viitanen-Vanamo.

1 E.g. Sakai 1993, Benefiel 2010, Baird/Taylor 2011, Sears/Keegan/Laurence 2013.

2 University of Helsinki 2011-2013, directed by Dr Kalle Korhonen and funded by the University of Helsinki.
}

DOI 10.1515/9783110534597-006, (๔) BY-NC-ND ( ) 2017 Eeva Viitanen, Laura Nissin, published by De Gruyter. This work is licensed under the Creative Commons Attribution-NonCommercial-NoDerivs 4.0 International License. 
texts on a map of Pompeii as accurately as possible and study their surroundings in detail. On which parts of the façades were the texts written? To what kind of houses were they connected? What were the streets in front of the façades like? What kind of activities could be connected to the streetscape in the immediate vicinity of the texts? A combination of a citywide perspective to the analysis of micro-topography is necessary as none of the approaches proposed sufficiently answers our questions. The aim of this paper is to analyze the electoral programmata, painted notices promoting candidates in the local elections, in their spatial, social and chronological contexts in order to reach a better understanding of the reasons for using them in the electoral process.

\section{Pompeian Electoral Programmata}

The electoral programmata are usually quite short notices painted on the wall plasters covering the façades of the city blocks; sometimes they can be found also on whitewashed stone or brick surfaces. ${ }^{3}$ There are some 2.500 certain programmata from Pompeii including the ones found in most recent excavations and published outside the volume IV of the Corpus Inscriptionum Latinarum. ${ }^{4}$ They are fairly formulaic texts promoting candidates in the local elections; usually they contain the name of the candidate, the office and rarely information of the person(s) asking for support for the candidate. The notice set up by fruit-vendors and Helvius Vestalis to support Marcus Holconius Priscus's campaign for getting elected as duumvir is a good example: M(arcum) Holconium / Priscum IIvir(um) i(ure) d(icundo) / pomari universi / cum Helvio Vestale rog(ant). ${ }^{5}$ Political slogans or qualities of the candidates are not very common, but, for example, the notices set up by pickpockets, sleepers and drinkers could have been intended to mock the candidate rather than to promote him. ${ }^{6}$ Most of the notices are dated to the last decades of Pompeii, from the 50 s to $79 \mathrm{CE} .^{7}$ Some earlier texts have been preserved usually painted on whitewashed walls and some of these probably date back all the way to $1^{\text {st }}$ century BCE. ${ }^{8}$ The texts have been used to study the political life, prosopography and many other aspects of the Pom-

3 Chiavia 2002; Varone/Stefani 2009 for photographs of the programmata.

4 Chiavia 2002, 48.

5 CIL IV 202. Other examples in Wallace 2005, xii-xvi.

6 CIL IV 575 (dormientes universi cum), 576 (furunculi rog(ant), 581 (seribibi universi rogant). The candidate is Cerrinius Vatia and the notices are located by consecutive doors (VII 2,40-41, VII 2,41-42 and VII 2,43-44), along a street with plenty of notices.

7 Chiavia 2002, 114-141.

8 Sakai 1993, Chiavia 2002, 122-126. 
peian elite, but relatively little has been said about the contexts where the texts were found. ${ }^{9}$

Relatively little is known of what was the process of setting up the notices, but it is generally accepted that someone had to pay for the process. The common text formula- "we ask you to vote candidate xy for office"-suggests that third parties, not the candidates themselves, were responsible for setting up the notices. The notices were painted by professionals, scriptores, and their work had to be compensated. The relationship between the candidates and the supporters has been discussed at length particularly from the point of view of how democratic the elections were and how much the supporters could influence their results. ${ }^{10}$

The distribution of the electoral notices has been plotted on maps in earlier studies. James Franklin presented distribution maps for individual candidates already in the 1970s in his study of Pompeian political life, but only a few of the maps from his notes were ultimately published. ${ }^{11}$ The most significant study of the programmata is Henrik Mouritsen's doctoral dissertation from 1988. ${ }^{12}$ He prepared a standardized map of the distribution of all the notices and thus established a general distribution pattern for the first time. The standardization was based on calculating the number of texts per façade meter. ${ }^{13}$ Consequently, Mouritsen was the first who was able to compare the distribution of the individual candidate's notices to a general pattern. The distributions of individual candidate's notices were used to locate the houses of the candidates and to analyze their strategies for promotion based on the location of their homes. ${ }^{14}$

Mouritsen's conclusions concerning the notices and their significance in the campaigns were not very encouraging for starting a new analysis. According to his interpretation, the notices were ritual in character, not really part of an active, democratic campaign-after all, the elite controlled the whole election process. ${ }^{15}$ Mouritsen thought that everyone had the right to paint notices on the walls of the city blocks. ${ }^{16}$ He also questioned the validity of the distribution pattern based on comparison of the Pompeian excavation history and the frequency of the notices. The areas in the western part of the city were excavated earlier and featured less notices than the sections excavated later. ${ }^{17}$ Particularly the last point is significant from the point of view

9 E.g. Castrén 1975, Gigante 1979, Franklin 1980, Mouritsen 1988, Chiavia 2002.

10 Mouritsen 1988, 44-69, Mouritsen 1999, Chiavia 2002, 227-258, Biundo 2003.

11 Franklin 1975, Franklin 1980. His unpublished materials could be consulted in the library of the American Academy in Rome.

12 Mouritsen 1988.

13 Mouritsen 1988, fig. 3.

14 Mouritsen 1988, figs. 5-8.

15 Mouritsen 1988, 44-56.

16 Mouritsen 1988, 59.

17 Mouritsen 1988, 49-50, figs. 3-4. 
of representability: what does the observed distribution represent? Is it roughly what the ancient Pompeiians really saw or merely a reflection of changing excavation documentation?

Despite the seemingly thorough discussion of the distribution, Mouritsen's analysis does leave space for new studies. Firstly, Mouritsen's distribution pattern was presented as lines along the façades, which imply indirectly that every spot on the façades was equally important and available for painting electoral notices. However, old photographs demonstrate clearly that clusters of notices and lengths of empty wall could be found even on the same façade. ${ }^{18}$ The standardized line along the façade wall indicates density, but does not represent the complexity of the distribution very well. Secondly, Mouritsen used only one comparative data set, excavation history, to evaluate the reliability of the distribution pattern. The development of documentation methods is an important factor in all Pompeian archaeology, ${ }^{19}$ but different data sets could have been used to test the results of the comparison. Thirdly, Mouritsen did not analyze the contexts of the notices beyond the city block and façade. Studying whether the notices were found on the walls of a private house or a shop is significant when considering the conclusion on who could and would paint notices and how the locations were selected.

\section{Different Data Sets}

Pompeii is perhaps the most well-known Roman city, but collecting a reliable and representative data set on almost any aspect of its archaeology or history is challenging. Only a few sources covering the entire city have been available in the past and the results of the recent wave of fieldwork and related studies are only beginning to emerge. Compiling a data set consisting of textual and archaeological evidence is a labor-intensive task. Five of the nine modern administrative regions of Pompeii (I, V, VI, VII, IX) were included in this study. The reason for this choice was related to resources of the project as well as to the availability of data: the eastern part of Pompeii (regions III and IV) is mostly unexcavated and little data is available on the housing units behind the façades. Regions II and VIII in the south-eastern and southwestern parts of the city feature relatively few electoral notices compared to the other areas and were also left out.

The texts were collected from a full-text online database, ${ }^{20}$ but their exact find locations had to be collected by hand from the printed corpus and counterchecked

18 Varone/Stefani 2009.

19 Allison 2004.

20 Epigraphik-Datenbank Clauss - Slaby: http://www.manfredclauss.de/gb/index.html (last accessed: 20.5.2016). 
with other data. Of the slightly more than 2.500 known notices 1.975 are located in the study area and 1.500 of them can be located accurately and with relative certainty. Only these 1.500 texts have been used in the following distribution maps. Mouritsen, for example, plotted all notices in his work without regard to how accurately or certainly their locations were known. The uncertain locations are usually found within the main distribution pattern and do not suggest significant anomalies.

The archaeological data was collected from a variety of recent studies concentrating on the central elements of the Pompeian streetscape. These elements are usually quite concrete and include public fountains, crossroad shrines and benches, which indicate activities by the local inhabitants. ${ }^{21}$ From the studies concerning streets and traffic on them, it was possible to outline the most frequently used routes for carriages. ${ }^{22}$ Shops and bars attracted people into the streets where they are found. Plotting them on a map was also an important part of the process. ${ }^{23}$ Bars could also be perceived to create rowdiness and unrest on the streets ${ }^{24}$ and another perhaps unwanted element often connected with them are prostitute's cribs and the purposebuilt brothel in the central part of Pompeii. ${ }^{25}$

The types of housing units are very important in the analysis and they were divided into four groups according to their size, ground plan (presence of atrium, peristyle, commercial and/or productive spaces) and decorative elements. Small shops and workshops usually also contained living quarters, but the houses included in the three other groups indicate that their owners were able and willing to invest in the comfort of living even when the property contained a shop or a workshop ${ }^{26}$ (table 1 ).

\section{Exploring Distributions: Loci Celeberrimi}

By plotting the 1.500 accurately placed electoral notices on a map, it becomes evident that the main streets starting from the gates in the perimeter walls of Pompeii are the most popular areas for painting notices (fig. 1). The main emphasis is on the central part of the city with fewer texts towards the edges. If the posters wanted visibility for their notices, the main streets are logical places for them. Romans had a clear idea

21 Public fountains: Jansen 2002; crossroad shrines: Van Andringa 2000; benches: Hartnett 2008.

22 Poehler 2006, Kaiser 2011, Weilguni 2011.

23 Shop doors based on visual inspection of topographical maps and photographs in Pompeii in Pictures: http://pompeiiinpictures.com/pompeiiinpictures/index.htm (last accessed: 20.5.2016); bars: Ellis 2004, Ellis 2006.

24 Wallace-Hadrill 1995, Laurence 2007, 81-101.

25 McGinn 2002, Guzzo/Scarano Ussani 2009.

26 More details in Viitanen/Nissinen/Korhonen 2013. See also Flohr 2012 for atrium houses and workshops. 
of where to find the 'busiest places', loci celeberrimi, ${ }^{27}$ for distributing information, propaganda and opinions. It obviously also worked in Pompeii.

Looking at the distribution more carefully indicates that not every location in the center of the city was equally good for placing notices. Availability of space seems to be an obvious explanation: the notices could be quite large and space for painting them could be regarded as a good thing. The descriptions of the find locations, old photographs and drawings, however, make it clear that sufficient space was not an issue. Some 1.100 of the notices were found right next to a doorway or between two adjacent doorways. Only about one hundred were located at a considerable distance from a doorway. Empty wall space without doors is available only in the side streets and their distribution is almost reverse to the distribution of the notices. Space had obviously very little to do with where the texts were painted, but a door was an important factor.

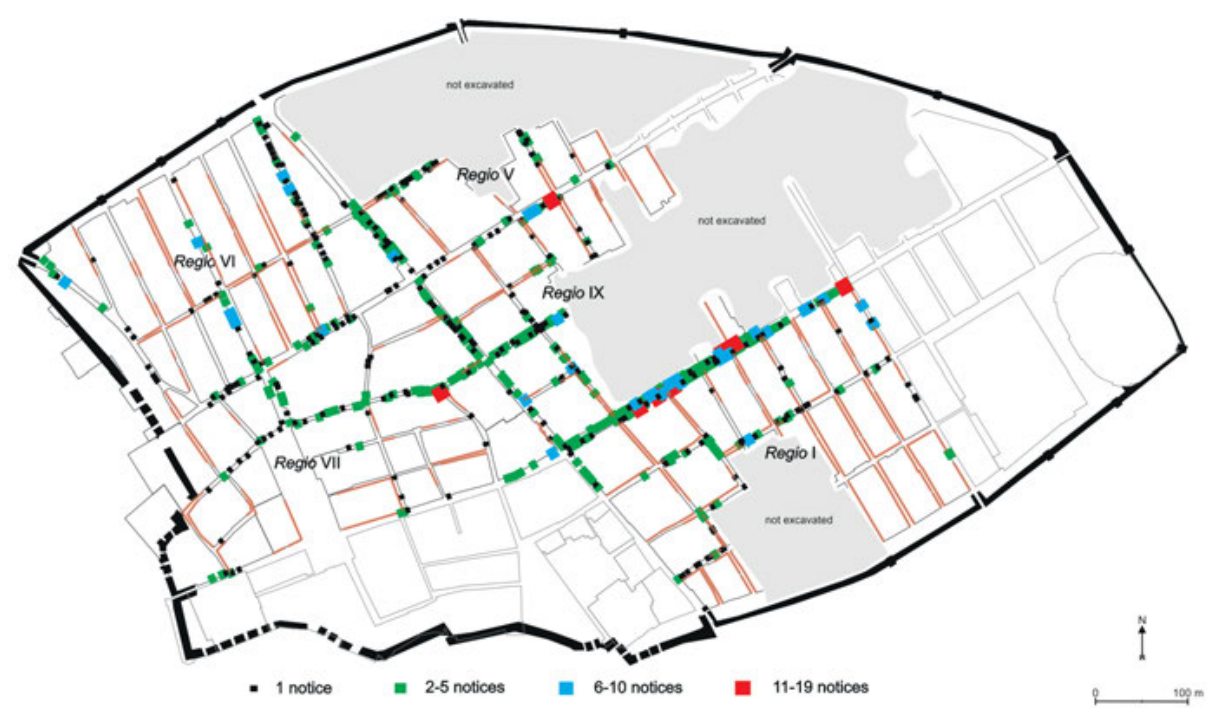

Fig. 1: The distribution of electoral notices in Pompeii. Walls without doors are indicated with red line (C) Eeva-Maria Viitanen.

The obvious places for painting notices were the façades along the main streets. The elements indicating street activity outlined in the previous section attracted people and helped to create an audience for the messages. The distribution of the street activities is almost identical to the distribution of the electoral notices (fig. 2). This reinforces the idea that they were, indeed, placed in the most visible and frequented places.

27 E.g. Newsome 2011. 


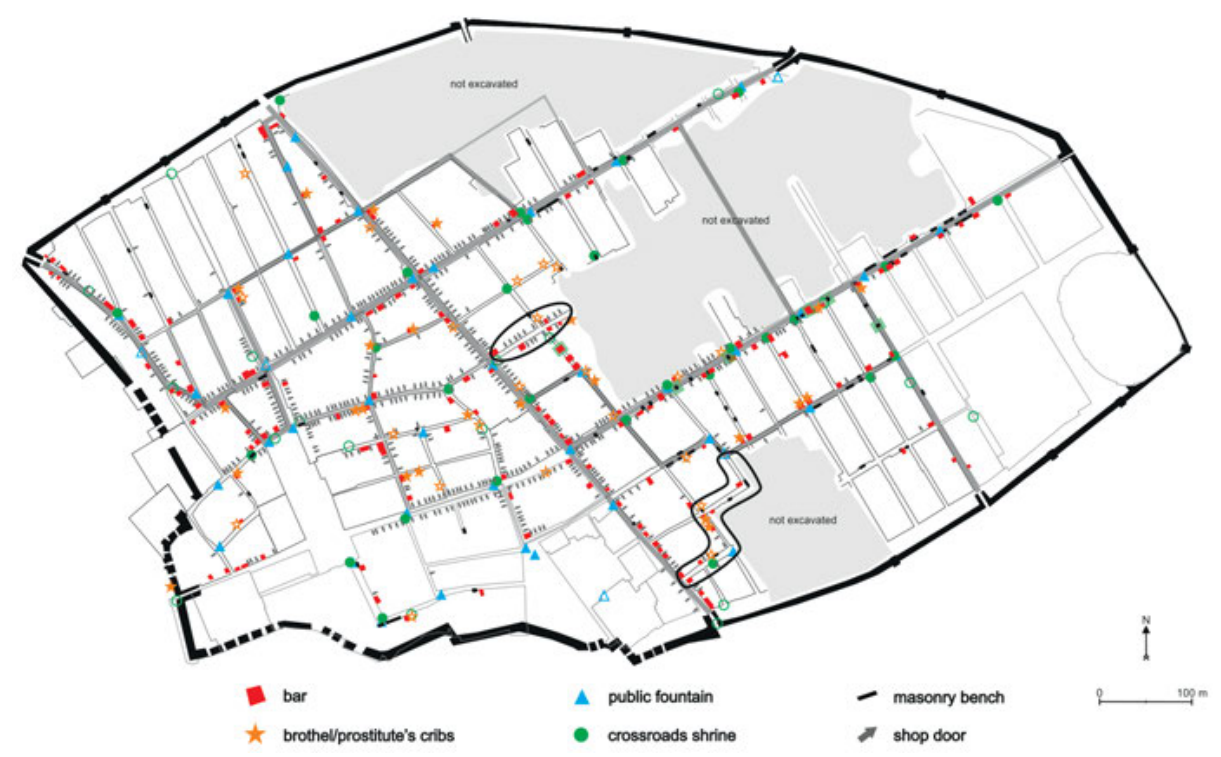

Fig. 2: The distribution of street activities in Pompeii. Empty symbols indicate uncertain cases. Routes for wheeled traffic are marked in grey lines along the streets. Anomalous streets with no wheeled traffic, but many electoral notices are circled with black () Eeva-Maria Viitanen.

The closest fit for the distribution pattern of the electoral notices is the probable routes used for wheeled traffic (fig. 2). There are two exceptions to this general trend. One of them is the west-east oriented street in the middle of region IX leading into the unexcavated area. Traffic routes there cannot be reconstructed, but recent geophysical surveys suggest, that this street continues directly eastwards all the way to the city wall and was probably a major traffic route in the area (fig. 2). ${ }^{28}$ This probably explains the frequency of notices in the western part of the street. The second exception is streets in region I in the southern part of Pompeii close to the gate. The streets with most notices are closed for wheeled traffic, but feature many elements of street activity which helped create an important walking route used in that part of the city and probably explains the large number of electoral notices on the walls.

The main distribution pattern is clearly not the result of a random choice of walls. The posters had a good idea where the largest audiences could be reached, i.e., what the loci celeberrimi of Pompeii were. It seems also likely that the distribution represents the actual situation in the last phase of the city and is not the result of changing excavation and documentation methods as suggested by Mouritsen. ${ }^{29}$ The documentation in the early days of the excavation was not up to modern standards and

28 Anniboletti/Befani/Boila 2009.

29 Mouritsen 1988, 49-50, figs. 3-4. 
many texts, particularly graffiti, certainly disappeared before they were recorded..$^{30}$ However, the electoral notices tend to be large, easier to note and less likely to be ignored than graffiti. There are more uncertain find locations in the old excavation areas in the western part of the town, but their suggested locations are still easily within the main distribution pattern. Some notices are surely missing, but the pattern represents probably quite well what could have been seen in Pompeii in 79 CE.

\section{Electoral Notices and Private Houses}

The presence of doors proved to be an important aspect in placing notices on the façades of the city blocks. There are close to one thousand doors in the study area and most of them lead into small combinations of shops, workshops and apartments that are commonly located on the main streets (fig. 2). The rest of the doors belong to modest dwellings and large or very large private houses (table 1). The entrances of most dwellings open onto the busiest streets, just like the shops and workshops (fig. 3). Shops, bars and other commercial establishments attracted people and it could be expected that most of the electoral notices were connected to them. In addition, the majority of the doors lead to shops and workshops and if visibility and audience were wanted, then the walls next to shop doors would probably be the places to post electoral notices. However, on average two notices were painted for each large dwelling in comparison to one for each shop-workshop.

Plotting the notices by the type of housing unit demonstrates the trends (fig. 3). The doorways to different types of housing units are located in different parts of the city blocks. Most doorways open onto the busiest street(s) around the city blocks as noted above.

Corner properties are usually used for commercial units such as bars and shopsworkshops and this is shown quite clearly in the distribution. The doors to private houses were in the central part of the façade and they were the most often used locations. On the secondary streets the walls around the doors of shops and bars are used more commonly than those around the doors of small and modest private houses. It is also quite striking to note the lack of electoral notices in the forum area and near other public buildings-some can be found on the façades of the shops and bars of the Stabian and Forum baths. ${ }^{31}$ Apart from the commercial properties connected to the bath buildings, the only public space with a fairly large number of electoral notices is

30 The situation in region VI was discussed in a poster by R.R. Benefiel presented at the XVIII AIAC Conference in Merida, Spain, in May 2013.

31 Some uncertain locations are reported in the portico on the south side of the forum as well as on the south and east façades of the Building of Eumachia. 
the palaestra and particularly its north wall. ${ }^{32}$ Otherwise private contexts were clearly sought after.

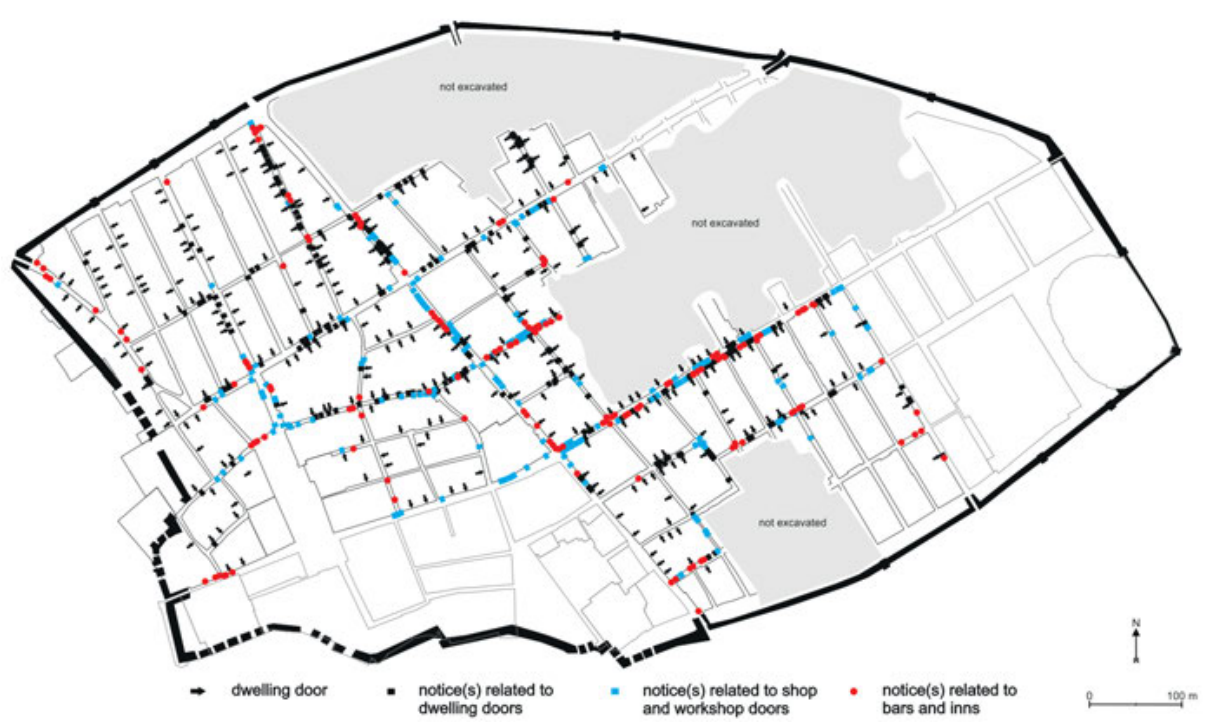

Fig. 3: Entrances to private dwellings and locations of electoral notices plotted by house type $\odot$ Eeva-Maria Viitanen.

Two data sets, independent of and yet related to the notices, have now been established and the distributions of street activity and entrances to houses match closely the distribution of the electoral notices. Consequently, in addition to concluding that electoral notices were most frequently placed along main streets, it is now possible to characterize the preferred locations more precisely: firstly, the street should preferably be suitable for wheeled traffic and also feature plenty of other kinds of activities, secondly, there had to be a lot of doorways, and thirdly, the doors should preferably lead into one of the larger dwellings in the city. Furthermore, electoral notices were generally not painted on public buildings. The close association of electoral notices, private property and large dwellings, makes one of Mouritsen's conclusions, that anyone could paint notices on any wall in Pompeii, seem rather doubtful. In the private contexts, the façades were integral parts of the houses and the house owners maintained also the sidewalks in front of their houses. ${ }^{33}$ The large houses were probably owned by the Pompeian elite and it seems unlikely that anyone could have painted anything without permission on the façade walls of some of the largest and most prestigious houses in the city. The distribution pattern is not the result of

32 Cf. Mouritsen 1988, fig. 3.

33 Saliou 1999. 
a random selection of location, but based on knowledge of the most visible places in the city. It is likely that careful planning and probably also negotiation with owners of the properties were needed to place the notices in the most sought-after locations.

\section{Campaigning for Offices}

Somewhat surprisingly, the distributions of notices for different offices were not discussed in previous studies. Elections were arranged annually and the candidates were running mainly for two offices: aedilis and duumvir. An aedile was the junior magistrate and his work consisted mostly of management of city maintenance and public buildings. The duumviri were mainly responsible for the administration of justice. Every five years duumviri iure dicundo quinquennales were elected to conduct the census of the population and the revision of the list of members of the ordo of Pompeii. Quinquennales was the most prestigious office, but they were also responsible for the duties of the ordinary duumviri who were not elected in those years. The people's assembly, the comitium, elected the magistrates. After serving as aedile, the magistrate could become member of the ordo decurionum, which was the city's legislative body and made the decisions that the magistrates implemented. ${ }^{34}$

In the 1.500 notices used in this study, 128 give the names of the candidates: 52 for aedile ( 870 notices) and 30 for duumvir (324 notices). The names of only nine candidates for quinquennalis are known (34 notices). There is some overlap as some of the persons were candidates for more than one office. The office is not mentioned in connection with 56 names ( 278 notices). The figures match the assumption that most candidates ran for aedile in order to get accepted to the ordo decurionum. There are fewer candidates for duumvir as the candidature required having served as aedile and the pool for candidates was therefore smaller. Candidates for quinquennalis could be derived from an even smaller group of mature and experienced men. ${ }^{35}$

Dating the elections and candidates is a complicated task and is usually based on other evidence mentioning names and events that can be dated. Most of the recorded notices belong to the last decade of Pompeii, between 69 and $79 \mathrm{CE}^{36}$ The only candidates dated with the accuracy of a year are those of 79 CE. 79 can usually be dated to a five-year or longer period of time rather than one specific year. A rough chronological division to four periods can be made: 79 CE, 75-79 CE, 70-75 CE and 69-79 CE. When these attributes-name, office and date-are used as filters of the original 1.500 notices, then roughly half of them (852) can be used.

34 Mouritsen 1988, 28-30, Chiavia 2002, 35-46.

35 Mouritsen 1988, 43-44.

36 Mouritsen 1988, 32-37 and passim in chapters with lists of magistrates and evidence for their dating, Chiavia 2002, 126-141. 
Most of these notices, 550 in total, roughly one third of all notices used in this study, were posted by the 24 candidates for aedileship between 69 and 79 CE. Usually only one candidate is named, but it was also possible to campaign together with candidates for other offices and joint notices are known (roughly 10\% of the named and dated notices). The distribution for aedile follows the main pattern neatly, which is to be expected as they form the majority of the notices (fig. 4).

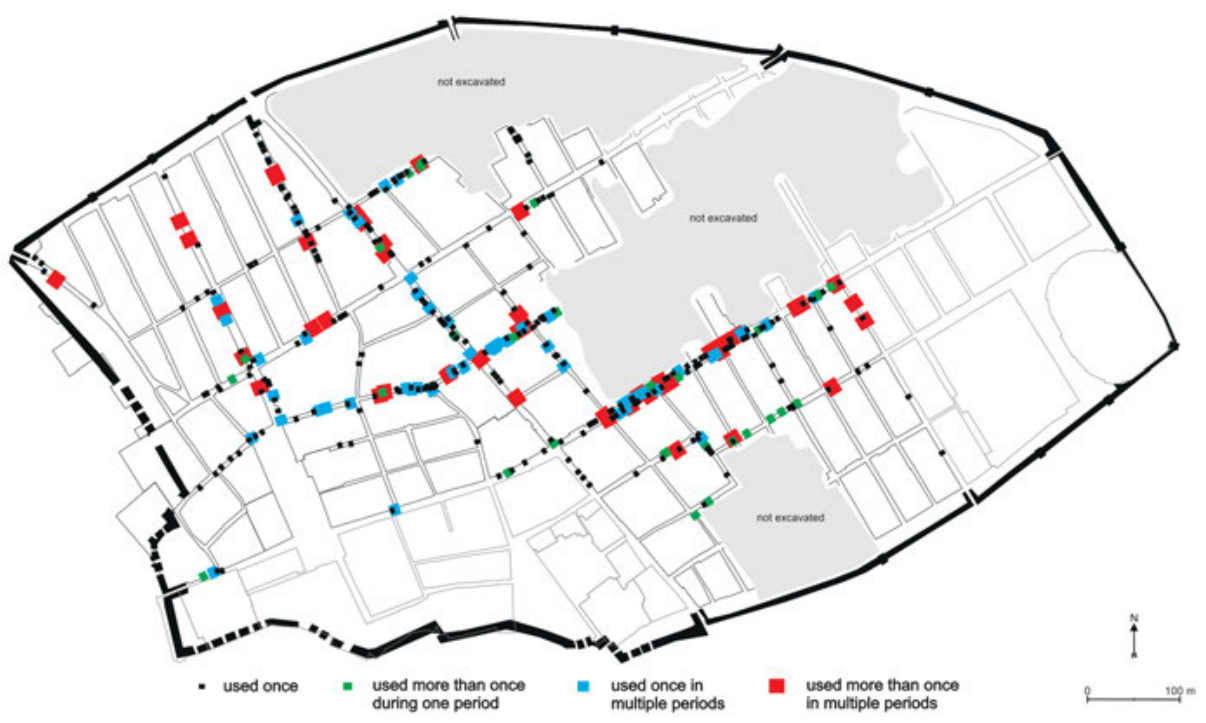

Fig.4: The distribution of notices for aedile in 69-79 CE @ Eeva-Maria Viitanen.

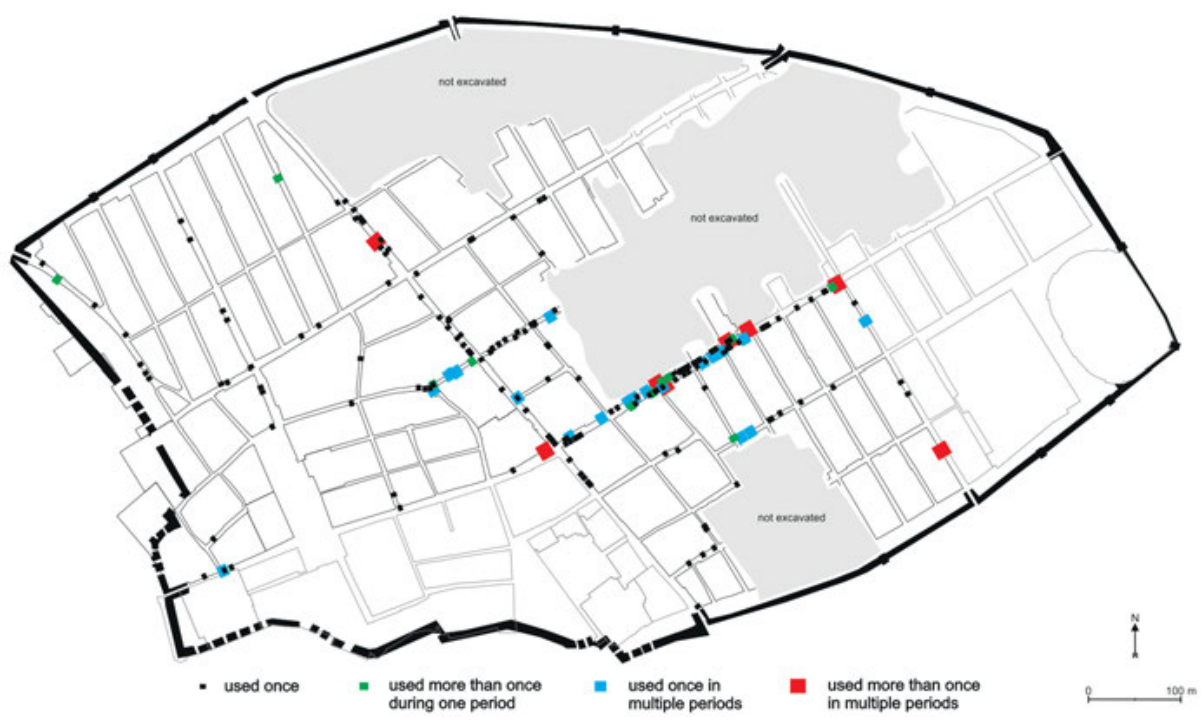

Fig.5: The distribution of notices for duumvir in 69-79 CE ๑ Eeva-Maria Viitanen. 
There are twelve candidates for duumvir between 69 and 79 CE and almost 220 notices were painted for their campaigns (fig. 5). Although the main pattern can still be recognized, their distribution is strongly placed in the eastern part of Pompeii. The pattern is the same for both offices in all the five periods: there were more candidates for aedile advertising in all the areas and the fewer candidates for duumviri posted mostly in the eastern part.

It is also interesting to note that the candidates for the two offices rarely advertised in the same locations. Only a few locations in all periods were used for promoting candidates for both offices and these tend to occur in the most frequently used locations. The same applies to candidates within one period: if more than one candidate was advertised in one location they usually had a joint campaign. Even the most popular locations were not used regularly in every election: they were probably not open for everyone. There is also a slight tendency towards posting more candidates and even rivals on bars and shops versus private houses-these locations were apparently open for all candidates. In the general distribution notices were placed on large private houses twice as often as on shops and bars, but in this group the relationship is roughly $1: 1$.

Based on the evidence of the distribution, the strong connection to private houses, the different patterns for different offices as well as for candidates, it seems clear that the candidates or supporters could not freely choose just any wall to post electoral notices, but either one or both parties had to be connected to the house owners socially or politically. The wall space was used most often only for one candidate and the notices were often not painted over even after the elections. It is possible to imagine that the house owners wanted to display the names of their political and/ or social associates on their façade, regardless whether their candidates lost or won the election. Bar and shop owners were apparently more open to allowing a variety of candidates running in the same elections to use their walls. It is also possible to think that whoever paid for the notices also paid the house owners for the privilege of using their walls, but even in this case there seems to have been a clear limit on how many and what kinds of candidates were allowed on one house façade in each election.

The notices for the last election in 79 CE represent a large proportion of the study material (240). They offer the only opportunity to analyze candidates in the same elections (fig. 6).

There were four candidates for aedile and two for duumvir. The duumvir candidates, Gavius Rufus and Holconius Priscus, joined forces with Cuspius Pansa and Popidius Secundus, who ran together for aedile. Their notices are concentrated in the central part of Pompeii from west to east. The other aedile pair, Helvius Sabinus and Samellius Modestus, who apparently received no help from candidates to the other office, advertised more in the northern and southern parts of town. The competing aedile and/or duumvir candidates advertised 14 times in the same locations and half of them are situated along the south main street. Only one of these notices is on the façade of a private house; in all other cases they are on the façades of shops or bars. 


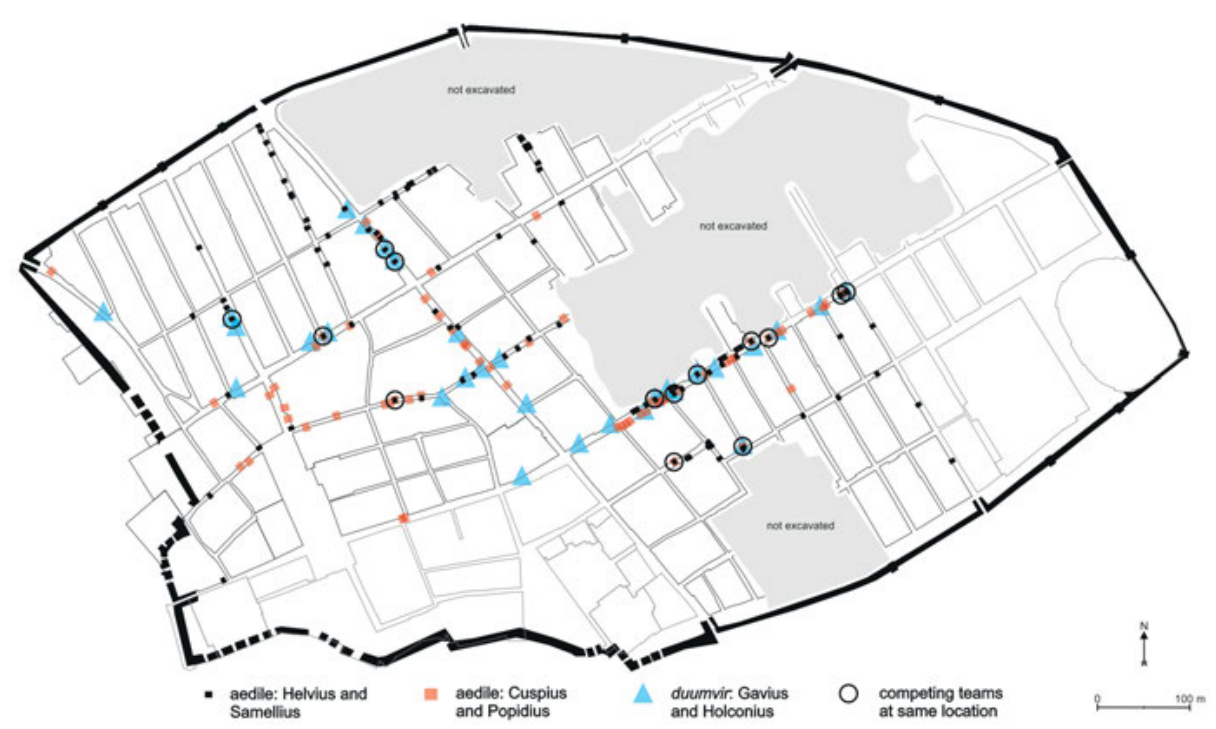

Fig. 6: The distribution of notices for the election of 79 CE @ Eeva-Maria Viitanen.

The notices for the individual duumvir candidates can be found mostly in the eastern part of Pompeii as in the other elections, but all the joint notices are located in the western part of the city. The opposing candidates maintained their distance within the usual patterns for advertising for each office.

It is difficult to know what lies behind the varying geographical distribution for the different offices. There are always more candidates for aedile than for duumvir and it is possible to imagine that the junior magistrates felt they had to advertise their candidacy more than the more experienced duumviri. But the numbers or the need to advertise more do not explain why the duumviri advertised mostly in the eastern part of town. The candidates and their supporters were maybe better connected in their respective areas, but there could also be more prestige connected to the central part of town possibly due to better visibility.

\section{Candidates, Supporters and Houses: Ownership or Coincidence?}

The previous analyses have concentrated on combined distributions of electoral notices, whereas in the two last sections distributions of individual candidates shall be analyzed. The number of notices for some 30 candidates is sufficiently high to allow a study of their distribution-they include representatives for all the periods and offices. The candidates were usually within the distribution patterns for the different 
offices, but individual strategies can also be discerned as anomalies to the distributions of the larger groups. Reasons for these strategies are difficult to understand, but it is possible, for instance, that the candidates directed their campaign towards their own neighborhood. Knowing where the candidates lived would be necessary to establish the neighborhoods, but although electoral notices have frequently been used to connect houses to candidates, the results remain uncertain. ${ }^{37}$

Two elements in the contents of the notices have been used to attribute houses to owners: names of those who support candidates themselves (rogatores) and of those who are recommended to vote for certain candidates. ${ }^{38}$ Such elements occur in some 385 accurately placed notices in the study area. The supporters form a majority as only 48 recommendations have been recorded. The candidates are supported by diverse groups of people: there are individuals on their own, groups of individuals up to three persons in size as well as professional and other groups (such as bakers or neighbors) on their own and together with other groups or individuals. In most cases, only one supporter per location (194 out of 274 locations, 71\%) can be found, but even as many as nine different supporters can be found on one façade. ${ }^{39}$ The general distribution of supported notices is similar to the main pattern, but there is an even stronger tendency to place them in the most central locations-particularly those of various groups (fig. 7).

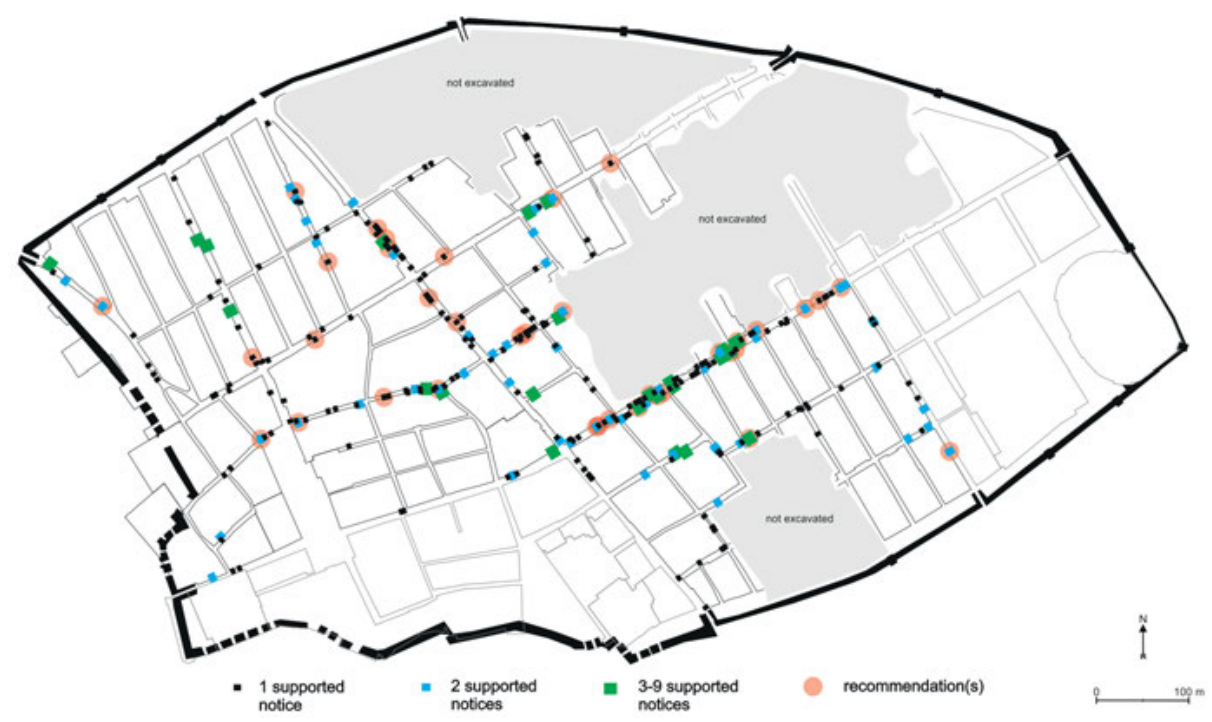

Fig. 7: The distribution of notices with supporters and recommendations (C Eeva-Maria Viitanen.

37 Della Corte 1965. See also Mouritsen 1988, 18-19, 61 and Allison 2001 for criticism.

38 Mouritsen 1988, 160-178, Chiavia 2002, 188-226, 328-368.

39 Two supporters in 54 locations (20\%, three in 18 locations (6\%), four in five locations (2\%) and 5 , 6 and 9 supports in one location. 
The important question concerning the supporters is their relationship to the location where their names appear. The assumption has been that they are either owners or tenants of the property on which the notice is painted. The recommendations have been regarded as the most reliable evidence for ownership of the premises. ${ }^{40}$ Neighbors (vicini) are the most important supporter group with a spatial connection-they are supposed to have posted their notices close to their own houses and consequently also the houses of the candidates. The candidates were persons with considerable economic means and consequently have usually been connected to the largest dwellings in the vicinity of the notices they supported, the notices supported by their neighbor and/or recommendations directed to them (table 2; fig. 8). However, there are some significant problems: Why are there so commonly many supporters on one wall? What is the connection between the groups and the houses? How close do the neighbors live? Is there any other kind of evidence of the house occupants?

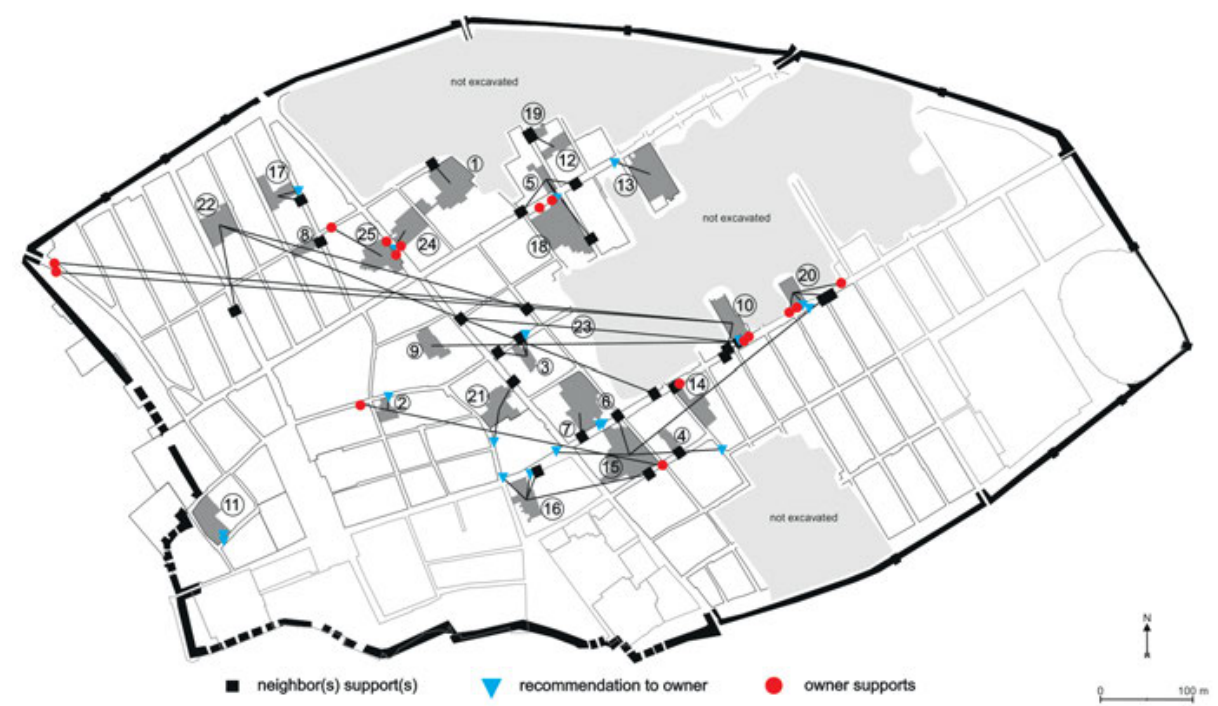

Fig. 8: Evidence used for house attributions of selected candidates and other persons. Numbers refer to data presented in table 2 (c) Eeva-Maria Viitanen.

The case of house I 7,1 is revealing. It is a finely appointed large dwelling with its main entrance onto one of the busiest streets in Pompeii. The notices on its façade include one with Paquius Proculus as rogator and another where Paquius is supported by his neighbors. ${ }^{41}$ Paquius Proculus does not appear as a supporter anywhere else. The attribution of the house to Paquius seems obvious, but other rogatores also

40 See above note 38.

41 CIL IV 7210 and 7197 respectively. 
occur: Amandio with his family/friends (sua), Fabius, Primanus and ordo supporting four other candidates. ${ }^{42}$ In addition, an electoral notice in the entrance hall promotes Cuspius Pansa along with a possible honorary painted text for Cuspius. ${ }^{43}$ Moreover, a candidate for aedile of an unknown date, Lollius Rufus, is mentioned in a graffito inside the house $\mathrm{e}^{44}$ and other person names occur in the other graffiti in the house as well. The other supporters could be interpreted as clientes or associates of the owner as they seem unlikely to be tenants-the house and its frontage feature no commercial spaces. From these kinds of lists of supporters the person perceived as the most prestigious one has usually been selected as the house owner. ${ }^{45}$

The case of the house of the Caecilii Iucundi (V 1,23/26) is also interesting, even though none of the family members was a candidate in the elections. The house can be relatively safely attributed to the family based on the archive of the banker Caecilius Iucundus found there. ${ }^{46}$ Family members appear in a recommendation placed across the street (VI 14,21) and support candidates in two notices on the house façade. ${ }^{47}$ Inside, there are two electoral notices, one for Numisius Rarus and another for Appuleius-a notice inside the house is not an indication of ownership of the candidate. ${ }^{48}$ There are also at least two other supporters ${ }^{49}$ connected with one of the shops between the entrances to the house. The recommendation for Iucundus to vote for Caecilius Capella is placed on the façade between a private house and a workshop both attributed to Vesonius Primus based on notices supported by him on the façades of both of these houses..$^{50}$ Vesonius appears as a supporter also on the opposite side of the city block VI 14 (unit 34). ${ }^{51}$ If the additional evidence connecting the Caecilii Iucundi to the other side of the street was unknown, it would be difficult to attribute ownership to the houses in either city block based on the notices. Moreover, the role of the supporters from the shop surrounded by the large house remains uncertainthey could be owners as well as tenants.

42 CIL IV 7213, 7205, 7212 and 7203 respectively.

43 CIL IV 7200, 7201. Cuspius has been suggested as an alternative owner, but for him there is another house attribution, house IX 1,22, where Cuspius is mentioned in two recommendations.

44 CIL IV 8128.

45 For example, House of the Menander (I 10,4) has never been attributed to Fulbunguis (CIL IV 7345), Infantio (CIL IV 7348) or Vatinia (CIL IV 7347) who all appear as supporters next to its main entrance.

46 Karivieri/Forsell 2007.

47 CIL IV 3473, 3428 and 3433 respectively.

48 CIL IV 3417 and 3416 respectively. There are altogether 37 cases of notices inside houses in the study area. Usually they are located in the entrance area, but there are also some that are clearly inside the house.

49 CIL IV 3241, 3423. One notice is fragmentary and the third name remains unknown.

50 VI 14,20 and VI 14,22; CIL IV 3471, 3477, 3478 and 3480.

51 CIL IV 3482. 
It is also apparent that one person could appear as a supporter in more than one location, as in the case of Vesonius Primus above or that of Iulius Polybius. Polybius set up supporter notices in three different places: two in region VI and one in region IX. ${ }^{52}$ The houses in region VI were probably bars and hospitia and Iulius Polybius is accompanied by muliones and Chypare as supporters-they could be explained as other properties owned by Polybius, but then the presence of the supporters remains unexplained. The large dwelling in region IX is attributed as Polybius's house based on the notices advertising for his candidacies as well as a recommendation for Polybius to vote for Rustius Verus on the façade. In addition, neighbors set up a supporter notice for Polybius in the next city block..$^{53}$ Notices for Iulius Polybius also occur in several places inside the house. ${ }^{54}$ However, two other supporters are present on the house façade: Sextilius and Prunicus. ${ }^{55}$ Moreover, neighbors support three other candidates on the façade. ${ }^{56}$ In addition, Iulius Philippus appears in a graffito in a lararium in the house as well as in a recommendation located across the street. ${ }^{57}$ Considering the evidence for a strong family presence in the house of the Caecilii Iucundi, it is possible that the two Iulii could both be owners and inhabitants of the house, but it still remains uncertain who Sextilius and Prunicus were.

In other cases where one name appears in more than one supporter notice or recommendation, homonymy creates problems when analyzing their locations-it is not possible to know whether the person is the same in all the cases. However, it can be said that supporter names appearing in diverse locations outnumber those close to each other. One person could set up notices in their name in different locations even quite far away from each other. More than one recommendation per person is rare, ${ }^{58}$ but even these can be in different locations; however, these locations tend to be close to each other. Connecting the person to the houses where their names appear remains difficult and uncertain even when there is more than one type of evidence available.

52 Locations are: VI 1,3-4 (CIL IV 98), VI 17,3-4 (CIL IV 114), IX 13,1-2 (CIL IV 7942, 7945), IX 13,2-3 (CIL IV 7954). Popidius Ampliatus and Trebius Valens are two other candidates with supporter notices in different parts of the city.

53 CIL IV 7925 on house IX 12,7.

54 Giordano/Casale 1990, 48 and 50, Giordano 1974, 27 nr. 11, 12 and 14.

55 CIL IV 7931 and 7941 respectively. Prunicus is also mentioned in a graffito on the façade (CIL IV 9112).

56 Trebius Valens (CIL IV 7927) has been attributed a house two blocks east and Gavius Rufus (CIL IV 7927) in region VII, but Helvius Sabinus (CIL IV 7928) remains without a house attribution. Helvius Sabinus has neighbor supporters in three locations: I 8,6-7 (CIL IV 7273), IX 3,25 (CIL IV 852), IX 13,1 (CIL IV 7928).

57 AE 1977, 219 = AE 1985, 285; recommendation CIL IV 7316 on house I 9,1.

58 Cuspius Pansa (CIL IV 1068, 1071 on IX 1,21-22 and IX 1,22-23), Loreius (CIL IV 7517, 7531, 7539, 7733 in regions II and III) and Trebius Valens (CIL IV 7429 on I 12, 3 and 7614, 7618, 7619, 7624 and 7632 in region III). Maybe also Astylus (CIL IV 7464 on I 13,3 and 7794 in region III), Graphicus (CIL IV 7649 and 7650 in region III) and Lutatius (CIL IV 7443 on I 12,5 and 7636 in region III). 


\section{Individual Strategies for Individual Candidates}

The above analysis on supporters and houses raises general questions of properties, ownership, tenancy and households that have not been discussed much in connection to Pompeii despite the frequent appearance of personal names. Archaeological evidence has been used to recognize property divisions, ${ }^{59}$ but it has to be remembered that one person could own several properties and that some properties could be rented to tenants. Large houses could be inhabited by an extended family, as was apparently the case for the Caecilii Iucundi. The writers of graffiti inside the houses should also be included in the discussion. ${ }^{60}$ Tenants and members of the household could have had permission to use the façades to promote their political agenda-or then they could have been under the strict control of the owner.

One case study where detailed analysis of property lines has been conducted is the city block IX $3 .^{61}$ Over 50 electoral notices are painted on its façades and they occur mostly along the busy western and southern street fronts. (fig. 9).

The first property is a small house (IX 3,1-2), located in the northwestern corner of the city block, containing domestic quarters, a shop and a workshop. Its west façade features 13 notices with a recommendation for Ubonius and a supporter notice by offectores ('dyers'). The workshop was probably used for dyeing, so the connection between the group and the house is understandable. ${ }^{62}$ On the north façade, there is also a notice with neighbors supporting Helvius Sabinus. The second property consists of a large dwelling (IX 3,5/24) and three small shop-workshops (IX 3,3, IX 3,4 and IX 3,6) and only eight notices belong to its façade. The notices feature Virrus Secundus and Sabinus as well as studiosus et pistor as supporter(s). A wall painting found inside the house IX 3,5/24 featuring writing equipment and a letter addressed to a Marcus Lucretius have resulted in an attribution to this man, otherwise unknown in Pompeian epigraphy. The large bakery (IX 3,11-12) in the southwest corner of the city block features eight notices on its façade with Proculus and neighbors as supporters. It is possible that the pistor mentioned above could refer to this bakery, but there are also prominent bakeries on the opposite side of the street in city block VII 2. The neighbors support Casellius Marcellus who has been attributed to a house across the street (IX 2,26) and another notice for him supported by neighbors was found towards the east end of the street (fig. 10). The bakery is followed by a small house (IX 3,13)

59 Craver 2010, Ynnilä 2013.

60 E.g. Benefiel 2010.

61 Ynnilä 2013. Ynnilä and the current authors have all participated in the University of Helsinki Pompeii Project studying this city block. The notices are: CIL IV 852-853, 857-859, 861-867, 875878, 880-881, 3256-3267, 3285-3286, 3288-3289, 3291a-b, 3292-3296, 3647-3648, 3650, 3656, 3664, $3672-3673,3682-3687$.

62 The same can be seen with regard to other professional groups: fullones (I 4,7-8; I 6,7-8; VI 14,22; VI 15,2) and pistores (VII 2,1-2; next door or opposite in I 8,6-7 and IX 3,4-5). 
with only one fragmentary notice on its façade. The next property consists of a fairly large dwelling (IX 3,15) and two shops-workshops (IX 3,14, IX 3,16), the façade of which features six notices with two supporters: Fabius Celer and an unknown person. The second vicini notice is located between this and the adjacent property, which covers the entire southeastern corner. This bakery (IX 3,19-20) and two shop-workshops (IX 3,17, IX 3,18) next to it feature 16 notices with at least six different supporters (one unknown). Casellius Marcellus gets a recommendation between the two workshops. On the façade towards east, neighbors support Vettius Caprasius Felix.

Altogether more than 25 candidates were supported. Casellius Marcellus was the most popular with ten notices on the west and south sides including two neighbor supporters and one recommendation. Vettius Caprasius Felix and Helvius Sabinus get fewer notices (four each) and also these were set up on different sides of the city block. Holconii and Postumii candidates are featured mostly on the west side and Suettii in the south side. There seems to be no preference of supporting candidates following the suggested property lines (fig. 9) or even individual houses, but rather along the sides of the city block facing the busiest streets. If Casellius really did live in the next block, he could have had the closest connection with the area and the possibility to get supported notices on most walls. He ran for aedile and has a large number of notices, the distribution of which follows the main aedile pattern. The greatest concentration of supporter notices for Casellius are located in the areas adjacent to city blocks IX 2 and IX 3 perhaps indicating his close relationship with the area (fig. 10).

If the current attributions for the candidate's houses are accepted, then some other cases of campaigns in the vicinity of the house could be suggested. Ceius Secundus has his notices for his duumvir campaign almost entirely in region I and most of them are also supported ( $n^{\circ} 4$ in table 2 and fig. 8 ). The few notices promoting Epidius Sabinus's campaign for duumvir are also located near the house and most of them are supported ( $\mathrm{n}^{\circ} 7$ in table 2 and fig. 8). The same applies to Iulius Polybius ( $\mathrm{n}^{\circ} 10$ in table 2 and fig. 8), Paquius Proculus ( $\mathrm{n}^{\circ} 14$ in table 2 and fig. 8 ) and Samellius Modestus ( $\mathrm{n}^{\circ} 19$ in table 2 and fig. 8 ) although not with as many supporters. In these cases it seems that the home neighborhood was where the most possibilities for gaining supporters and advertisement space were available. For equally many others there does not seem to be any connection between the distribution of the notices, supporters and the suggested house of the candidate. Diverse strategies could be employed for promoting the candidates both locally and in the whole city. 


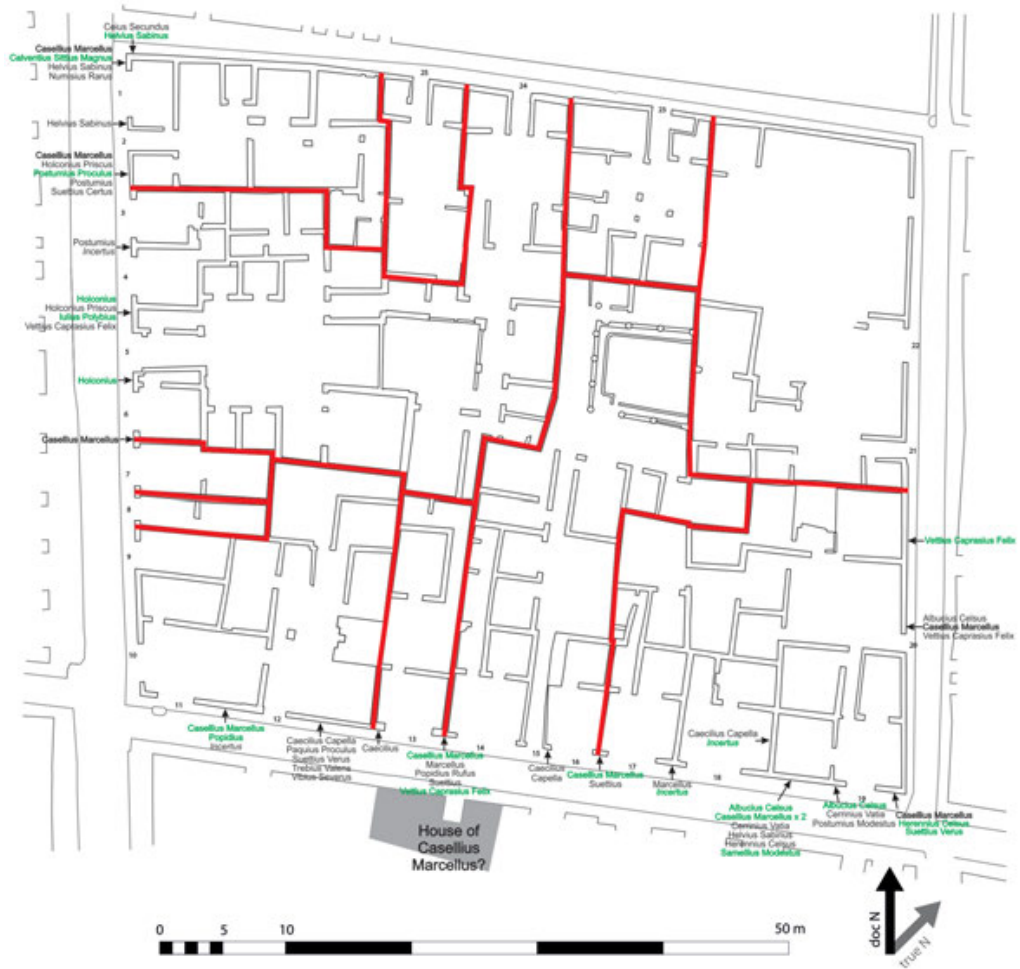

Fig. 9: The distribution of electoral notices on the facades of city block IX 3. Property lines are in red. Supported notices are marked with green (c) Expeditio Pompeiana Universitatis Helsingiensis/Maija Holappa and Eeva-Maria Viitanen.

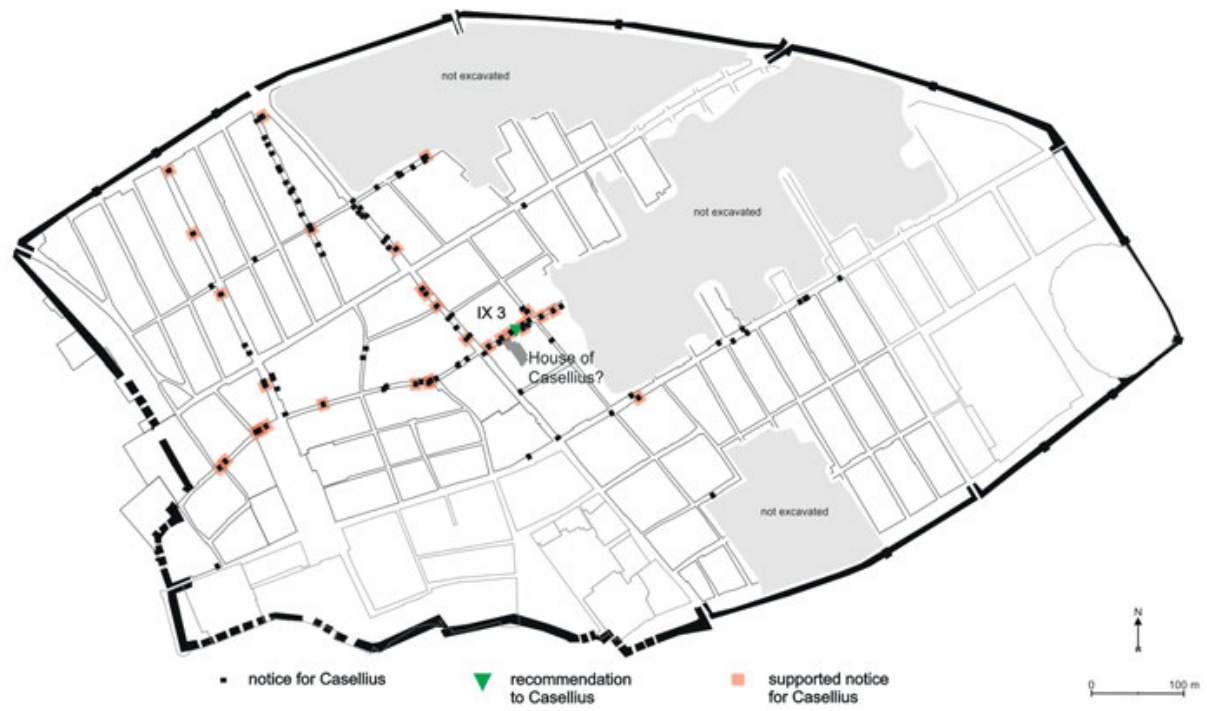

Fig. 10: The distribution of notices for Casellius Marcellus ( Eeva-Maria Viitanen. 


\section{Conclusion}

Previous research on the distribution of Pompeian electoral notices has concentrated on the content of the notices and taken little interest in their contexts. Using the best evidence available, a variety of data sets and different levels of analysis, new insights into the electoral campaigns and promoting candidates could be reached. Comparison of the general distribution to street activity indicates that the busiest places were sought for the notices. Their strong connection with large private houses suggests that painting notices on house façades was not possible without permission. The large dwellings indicate the importance of the elite in the process, but many small houses and commercial locations, possibly in the hands of non-elite owners, were part of the campaigns as well. Comparison of the distribution of the earlier notices, possibly dating back even a century, with the last phase notices, shows that programmata have been painted in similar locations for a longer period of time. Analyzing the distribution of the notices for the two main offices, demonstrates differences in preferred areas for candidates running for aedile and duumvir in the city, repeated at least for the last decade of Pompeian elections. Few walls-however centrally located-were used repeatedly for both kinds of candidates in different elections. Evaluation of reasons for distribution of notices for individual candidates is made difficult by the poor understanding of the relationship between the candidates, their supporters and the locations where the notices were set up. If house attributions for candidates suggested by previous research are accepted, individual strategies for campaigns can be discerned: some based on neighborhood support and some on dispersing the notices city-wide. However, detailed studies of evidence for properties and households in Pompeii based on archaeological and epigraphic evidence are needed before these strategies may be verified. The analyses indicate that much attention was paid to placing the notices for campaigns of candidates for the local elections in Pompeii. The distributions were not based on available space or random selection. They were probably a result of careful thought and negotiation between the candidates, their supporters and house owners. 
Table 1: Different house types and their numbers in Pompeii.

\begin{tabular}{|c|c|c|}
\hline Houses & Description & Number \\
\hline Group 1 & Small workshop-shop and/or dwelling, no status architecture & 628 \\
\hline Group 2 & $\begin{array}{l}\text { Medium-sized dwellings, atrium or peristyle and/or commercial } \\
\text { area }\end{array}$ & 121 \\
\hline Group 3 & Large dwellings, atrium, peristyle and/or commercial area & 104 \\
\hline Group 4 & $\begin{array}{l}\text { Very large dwellings, multiple atria and/or peristyles and/or } \\
\text { commercial area }\end{array}$ & 74 \\
\hline Other & Public buildings, unbuilt plots, etc. & 42 \\
\hline
\end{tabular}




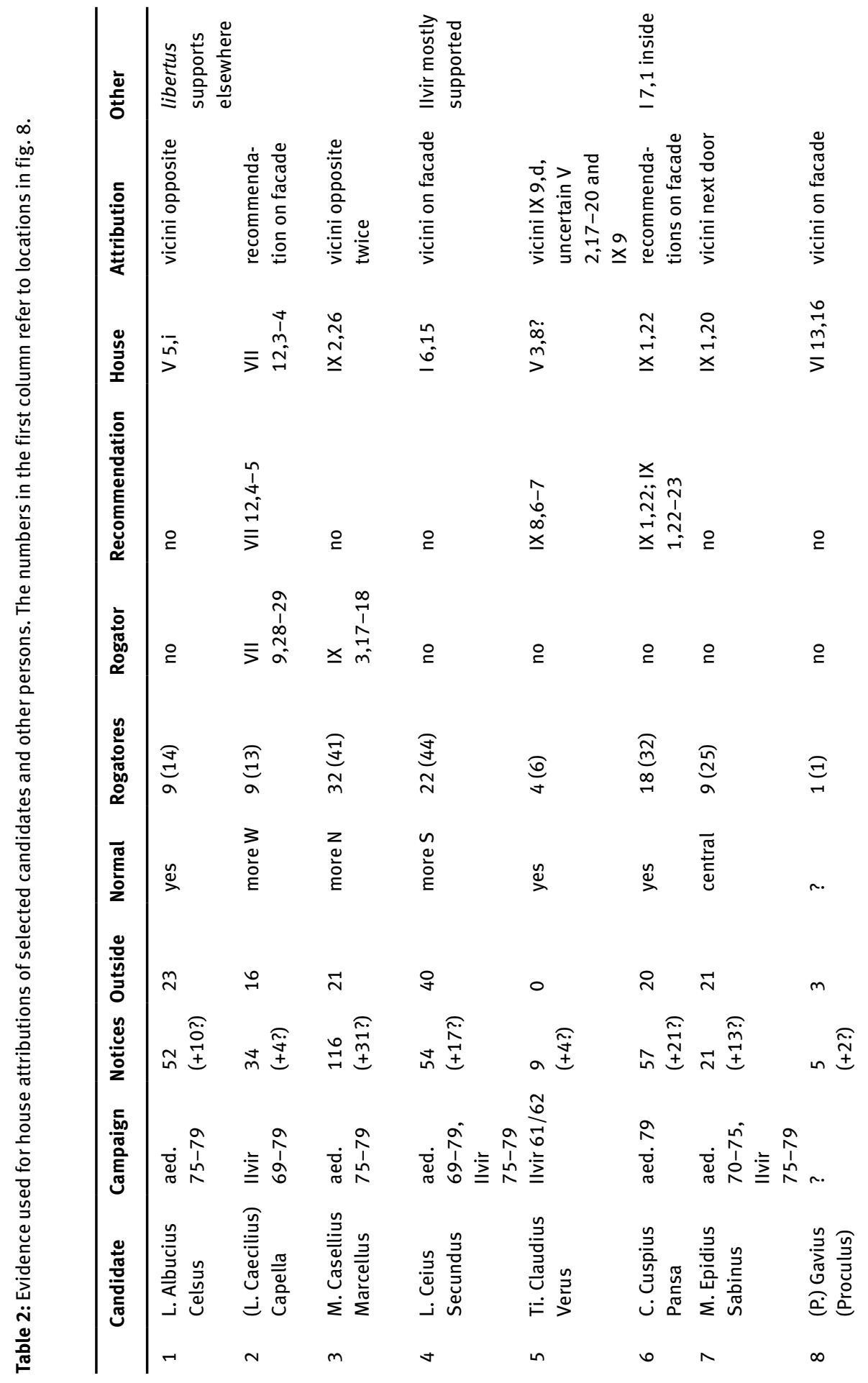




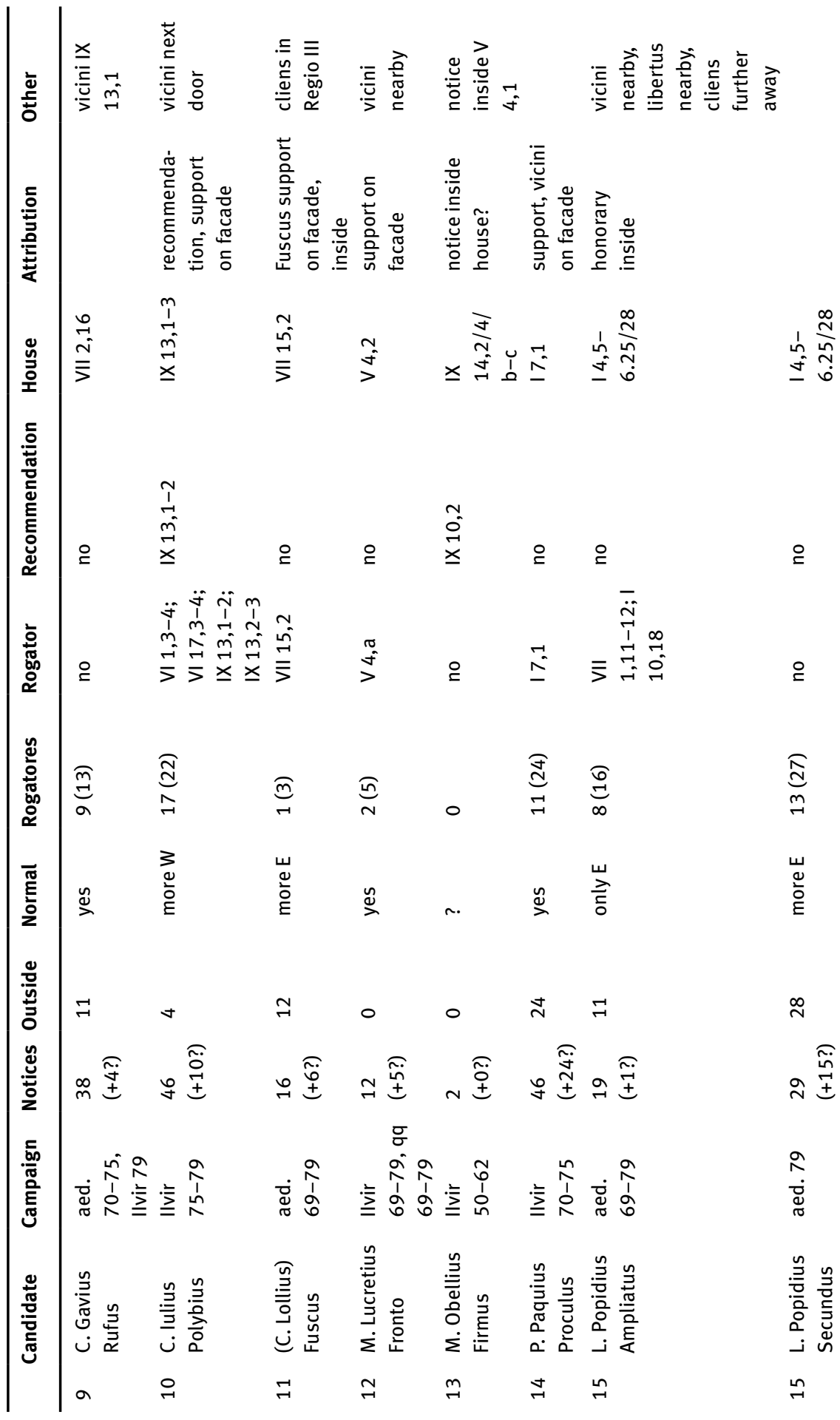




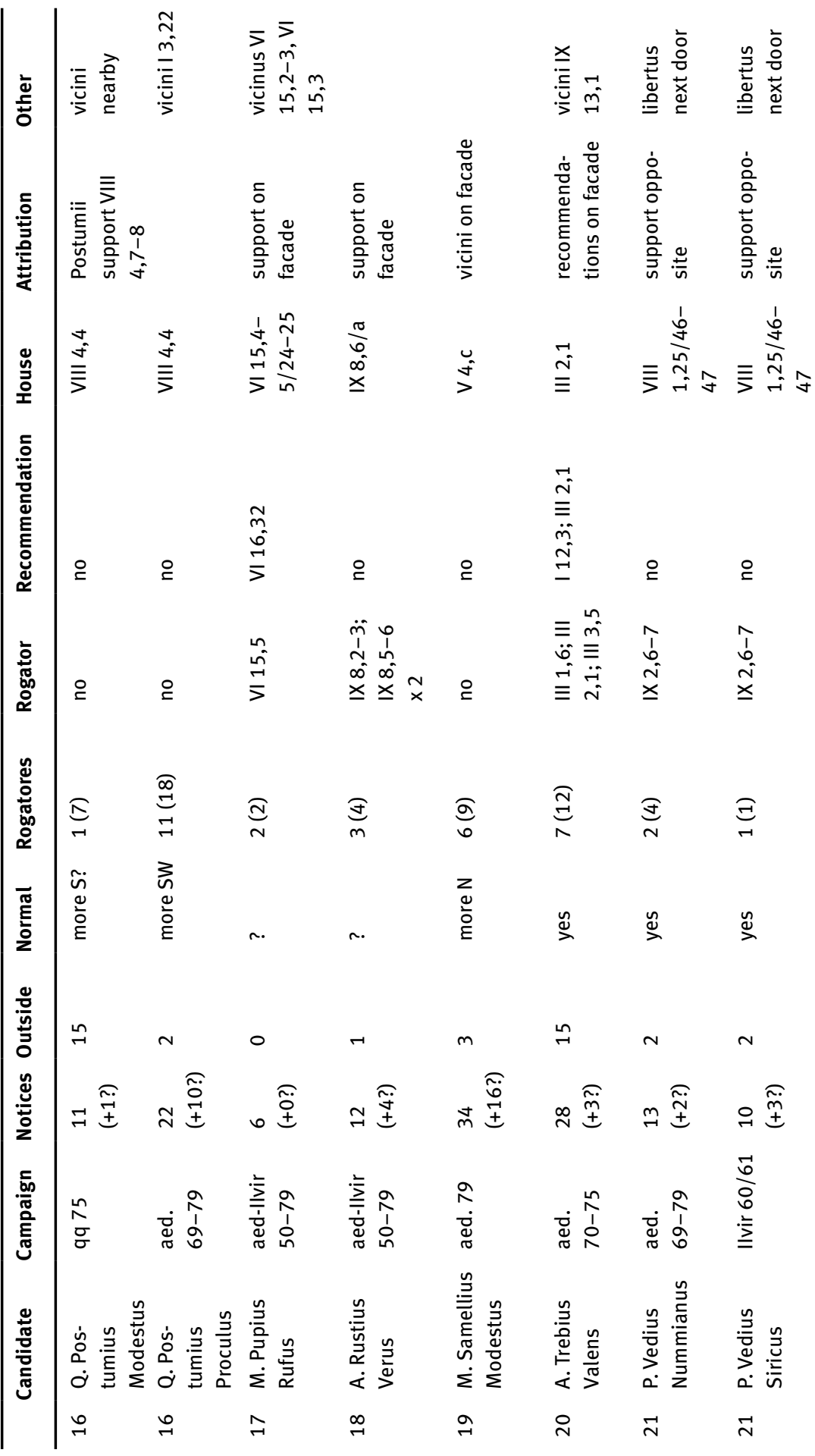




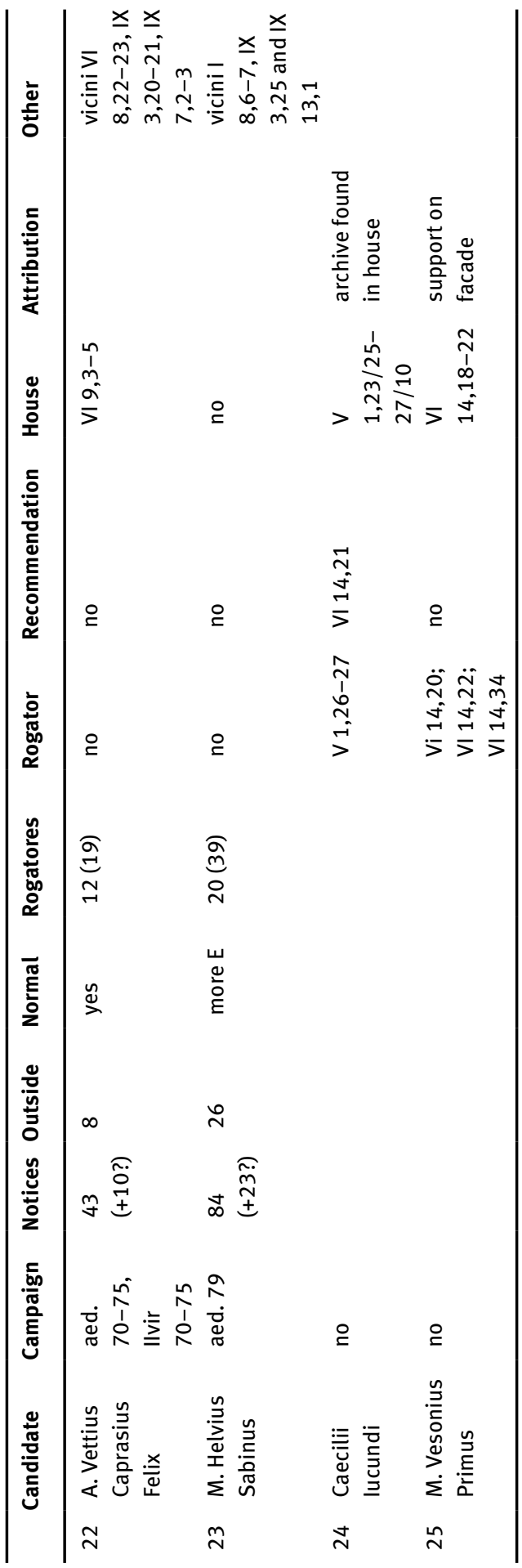




\section{Bibliography}

Allison, Penelope M. (2001), “Placing Individuals: Pompeian Epigraphy in Context”, in: Journal of Mediterranean Archaeology 14, 53-74.

Allison, Penelope M. (2004), Pompeian Households: An Analysis of Material Culture, Los Angeles.

Anniboletti, Lara/Befani, Valentina/Boila, Paolo (2009), "Progetto 'Rileggere Pompei': per una nuova forma urbis della città. Le indagini geofisiche nell'area non scavata e l'urbanizzazione del settore orientale", in: Fasti Online Documents \& Research 148 <http://www.fastionline.org/ docs/FOLDER-it-2009-148.pdf> (last access: 20.5.2016).

Baird, Jennifer A./Taylor, Claire (eds.) (2011), Ancient Graffiti in Context, New York.

Benefiel, Rebecca R. (2010), "Dialogues of Ancient Graffiti in the House of Castricius Maius in Pompeii”, in: American Journal of Archaeology 114, 59-101.

Biundo, Raffaella (2003), “La propaganda elettorale a Pompei: la funzione e il valore dei programmata nell'organizzazione della campagna”, in: Athenaeum 91, 53-116.

Castrén, Paavo (1975), Ordo populusque Pompeianus. Polity and Society in Roman Pompeii (Acta Instituti Romani Finlandiae 8), Rome.

Chiavia, Catherine (2002), Programmata. Manifesti elettorali nella colonia romana di Pompei, Turin. Craver, Scott (2010), Patterns of Complexity: An Index and Analysis of Urban Property Investment at Pompeii, unpubl. PhD Thesis, University of Virginia \& McIntire Department of Art.

Della Corte, Matteo (1965), Case ed abitanti di Pompei, Rome.

Ellis, Steven J. R. (2004), "The Distribution of Bars at Pompeii: Archaeological, Spatial and Viewshed Analyses", in: Journal of Roman Archaeology 17, 371-384.

Ellis, Steven J. R. (2006), “The Use and Misuse of 'Legacy Data' in Identifying a Typology of Retail Outlets at Pompeii”, in: Internet Archaeology $24<$ http://intarch.ac.uk/journal/issue24/ellis_ index.html (last access 20.5.2016).

Flohr, Miko (2012), “Working and Living Under One Roof: Workshops in Pompeian Atrium Houses", in: Anna Anguissola (ed.), Privata Luxuria - Towards an Archaeology of Intimacy: Pompeii and Beyond. International Workshop, Center for Advanced Studies, Ludwig-Maximilians-Universität München (24-25 March 2011), Munich, 51-72.

Franklin, James L. (1975), The Chronology and Sequence of Candidacies for the Municipal Magistracies Attested in the Pompeian Parietal Inscriptions A.D. 71-79, unpubl. PhD Thesis, Duke University.

Franklin, James L. (1980), Pompeii: The Electoral programmata, Campaigns and Politics, A.D. 71-79, Rome.

Gigante, Marcello (1979), Civiltà delle forme letterarie nell'antica Pompei, Naples.

Giordano, Carlo/Casale, Angelandrea (1990), “Iscrizioni pompeiane inedite scoperte tra gli anni 1954-1978", in: Atti della Accademia Pontaniana n.s. 39, 273-378.

Giordano, Carlo (1974), “Iscrizioni graffite e dipinte nella casa di C. Giulio Polibio”, in: Rendiconti della Accademia di archeologia, lettere e belle arti 49, 21-28.

Guzzo, Pietro Giovanni/Scarano Ussani, Vincenzo (2009), Ex corpore lucrum facere: la prostituzione nell'antica Pompei, Rome.

Hartnett, Jeremy (2008), “Si quis hic sederit: Streetside Benches and Urban Society in Pompeii”, in: American Journal of Archaeology 112, 91-119.

Jansen, Gemma C. M. (2002), Water in de Romeinse stad: Pompeji, Herculaneum, Ostia, Leuven.

Kaiser, Alan (2011), Roman Urban Street Networks, New York.

Karivieri, Arja/Forsell, Renée (2007), "The House of Caecilius lucundus, V 1,22-27: A Preliminary Report”, in: Opuscula Romana 31/32, 119-134.

Laurence, Ray $\left(2007^{2}\right)$, Roman Pompeii, Space and Society, London. 
McGinn, Thomas A. J. (2002), “Pompeian Brothels and Social History”, in: Thomas McGinn, Paolo Carafa, Nancy de Grummond, Bettina Bergmann and Tina Najbjerg (eds.), Pompeian Brothels, Pompeii's Ancient History, Mirrors and Mysteries, Art and Nature at Oplontis, \& the Herculaneum 'Basilica', Portsmouth, 7-46.

Mouritsen, Henrik (1988), Elections, Magistrates and Municipal Élite: Studies in Pompeian Epigraphy, Rome.

Mouritsen, Henrik (1999), “Electoral Campaigning in Pompeii: A Reconsideration”, in: Athenaeum $87,515-523$.

Newsome, David J. (2011), “Introduction: Making Movement Meaningful”, in: Ray Laurence and David J. Newsome (eds.), Rome, Ostia and Pompeii: Movement and Space, Oxford, 1-54.

Poehler, Eric E. (2006), “The Circulation of Traffic in Pompeii’s Regio VI”, in: Journal of Roman Archaeology 19, 53-74.

Sakai, Satoshi (1993), "Topographical Distribution of the so-called programmata antiquissima”, in: Opuscula Pompeiana 3, 89-104.

Saliou, Catherine (1999), “Les trottoirs de Pompéi: une première approche”, in: BABESCH Bulletin Antieke Beschaving 74, 161-218.

Sears, Gareth/Keegan, Peter/Laurence, Ray (eds.) (2013), Written Space in the Latin West, 200 BC to $300 A D$, London.

Van Andringa, William (2000), "Autels de carrefour, organisation vicinale et rapports de voisinage à Pompéi”, in: Rivista di Studi Pompeiani 11, 47-86.

Varone, Antonio/Stefani, Grete (2009), Titulorum Pictorum Pompeianorum qui in CIL Vol. IV collecti sunt Imagines (Studi della Soprintendenza archeologica di Pompei 29), Rome.

Viitanen, Eeva-Maria/Nissinen, Laura/Korhonen, Kalle (2013), "Street Activity, Dwellings and Wall Inscriptions in Ancient Pompeii: A Holistic Study of Neighbourhood Relations.", in: Annabel Bokern, Marion Bolder-Boos, Stefan Krmnicek, Dominik Maschek and Sven Page (eds.), TRAC 2012. Proceedings of the Twenty Second Annual Theoretical Roman Archaeology Conference, Frankfurt 2012, Oxford, 61-80.

Wallace-Hadrill, Andrew (1995), “Public Honour and Private Shame: The Urban Texture of Pompeii”, in: Tim J. Cornell and Kathryn Lomas (eds.), Urban Society in Roman Italy, London, 39-62.

Wallace, Rex E. (2005), An Introduction to Wall Inscriptions from Pompeii and Herculaneum, Wauconda.

Weilguni, Marina (2011), Streets, Spaces and Places. Three Pompeian Movement Axes Analysed (Boreas 33), Uppsala.

Ynnilä, Heini (2013), “Understanding Neighbourhood Relations through Shared Structures: Reappraising the Value of Insula-Based Studies", in: Annabel Bokern, Marion Bolder-Boos, Stefan Krmnicek, Dominik Maschek and Sven Page (eds.), TRAC 2012. Proceedings of the Twenty-Second Annual Theoretical Roman Archaeology Conference, Frankfurt 2012, Oxford, 81-90. 